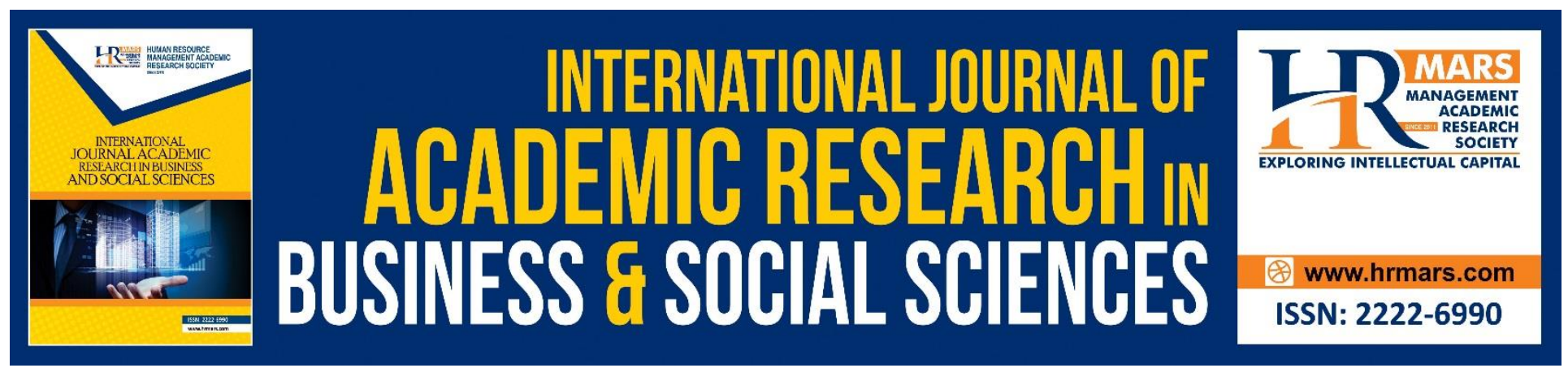

\title{
Needs Analysis of Scaffolding Literacy (ScafoLIT) Module in Helping Remedial Students Mastering Reading Comprehension Skills
}

\section{Ramli Hasan \& Noor Aini Ahmad}

To Link this Article: http://dx.doi.org/10.6007/IJARBSS/v9-i1/5397

DOI: $\quad 10.6007 /$ IJARBSS/v9-i1/5397

Received: 18 Dec 2018, Revised: 09 Jan 2019, Accepted: 29 Jan 2019

Published Online: 06 Feb 2019

In-Text Citation: (Hasan \& Ahmad, 2019)

To Cite this Article: Hasan, R., \& Ahmad, N. A. (2019). Needs Analysis of Scaffolding Literacy (ScafoLIT) Module in Helping Remedial Students Mastering Reading Comprehension Skills. International Journal of Academic Research in Business and Social Sciences, 9(1), 284-295.

\section{Copyright: (C) 2019 The Author(s)}

Published by Human Resource Management Academic Research Society (www.hrmars.com)

This article is published under the Creative Commons Attribution (CC BY 4.0) license. Anyone may reproduce, distribute, translate and create derivative works of this article (for both commercial and non-commercial purposes), subject to full attribution to the original publication and authors. The full terms of this license may be seen at: $\underline{\text { http://creativecommons.org/licences/by/4.0/legalcode }}$

Vol. 9, No. 1, 2019, Pg. 284 - 295

Full Terms \& Conditions of access and use can be found at http://hrmars.com/index.php/pages/detail/publication-ethics 


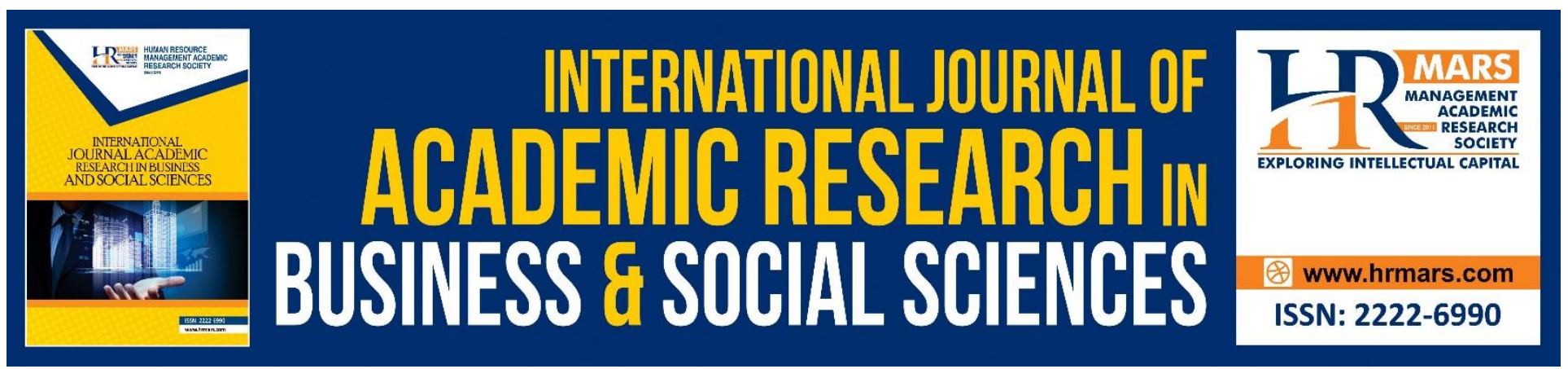

\title{
Needs Analysis of Scaffolding Literacy (ScafoLIT) Module in Helping Remedial Students Mastering Reading Comprehension Skills
}

\author{
Ramli Hasan \& Noor Aini Ahmad \\ Department of Special Education, Faculty of Human Development, Universiti Pendidikan Sultan \\ Idris, Malaysia.
}

\begin{abstract}
Malay Language Literacy is the most important skills for all students to survive in the Malaysia educational systems. Reading comprehension is one of the skills that need to be gained by the students in the early age of school to ensure that they can perform well in the school. The aim of this study is to investigate the needs and the element that proposed by remedial education teachers for constructing reading comprehension learning modules named Scaffolding Literacy (ScafoLIT). This study was conducted using a survey design which involved 53 respondents among remedial education teachers in Daro District, Sarawak. The instrument used to collect research data was the Module Needs Analysis Questionnaire. Research finding shows that the participants agreed that there is a need to construct a reading comprehension learning module for remedial students with the mean value of $M=3.71$. This mean value shows that there is a high agreement among the participants about the need to construct a new learning module for remedial students. The three themes suggested by the participants to be included in the module are; Family with a mean value of $M=4.15$, Culture with a mean value of $M=4.08$ and Nature Conservation with a mean value of $M=4.09$. While the suggested learning activities to be included in the learning module is (i) read aloud (M=3.89), (ii) oral communication ( $M=3.96)$, (iii) coloring $(M=3.91)$, (iv) match words with pictures $(M=3.91),(v)$ match sentences with pictures $(M=3.96)$. Finding of this study is clearly shown that there is a need to construct a reading comprehension learning module in order to help remedial students to overcome their difficulties in mastering the reading comprehension skills.
\end{abstract}

Keywords: Remedial Students, Literacy and Numeracy Screening (LINUS), Reading Comprehension.

\section{Introduction}

Malaysia Education Blueprint 2013-2025 has set a target of a reduction in the 50 percent achievement gap between urban-rural, gender and socioeconomic (Ministry of Education Malaysia, 2013). In order to achieve this goal, it is essential that literacy capability to be the most basic skill for 
all students to continue the learning process at school. Each student needs to have a full literacy and numeracy capability at the most basic level at the lower primary level. Support and guidance will be given to any student who has difficulty in mastering reading and writing skills so that they are on the same platform with other students (Ministry of Education Malaysia, 2013). Thus, this study is an initiative to achieve the government 's aspirations set out in Malaysia Education Blueprint by exploring the needs to construct a new learning module which is appropriate for teaching and learning activities of the remedial students. At the same time, the findings of this study will show the suitable content and suggested teaching activities that are suitable for remedial students.

\section{Literature Review}

The literature review includes reading comprehension among remedial students, scaffolding for remedial students, an intervention program for remedial students.

\section{Reading Comprehension Among Remedial Students}

Reading literacy is an important transversal competence for private, professional and public life. It is considered as a means of development of personality and society as a whole (Dolezalova, 2015). Reading literacy is a comprehensive competence requiring active thinking while reading. Without that reading is doomed to be ineffective (Ronkova \& Wildova, 2016).

Comprehension is the understanding and interpretation of what is read (Zhussupova \& Kazbekova, 2016). Students with specific poor comprehension can sound out words accurately, but have difficulty understanding what they read (Sung \& Shu, 2017). Reader's level of vocabulary knowledge is one of the elements that plays an impacting role in determining reading comprehension performance in that language (Sidek \& Abdul Rahim, 2015).

Struggling readers or remedial students tend to do poorly in word recognition, fluency, and reading comprehension (Cirino et al., 2013). Lack of proficiency in the primary grades often leads to continued difficulty in reading in succeeding grades (Rasinski, 2016). Thus, remedial teachers must play an active role in identifying problem that's been faced by remedial students in reading literacy to make sure that they are not left behind the other peers. This proactive action surely will bring benefit to remedial teachers and students.

\section{Scaffolding for Remedial Students}

The metaphor of scaffolding can be used to describe expert guidance in many different situations, including those that involve more than one adult and one child (Moschkovich, 2015). Scaffolding is a method of adapting teaching to the individual needs of students in the classroom (Pfister, Moser Opitz, \& Pauli, 2015). Providing learning support which is contingent on learners' needs when errors occur is considered effective for developing learners understanding (Wischgoll, Pauli, \& Reusser, 2015). Scaffolding is an important tool for meeting the challenging needs of heterogeneous groups of students in inclusive classrooms. It is especially useful when supporting low achievers (Pfister et al., 2015). 
Teachers' adaptive scaffolding means are based on a diagnosis of the situation and can be described as an independence-preserving form of support, adapted in form and content to students' learning process, in order to enable them to overcome a (potential) barrier in the process and to continue the process as independent as possible (Tropper, Leiss, \& Hanze, 2015). Scaffolding involves teacher's behavior shaping according to the learner's needs, but this simplification is not for the task itself, but rather it is more related with the simplification of the learner's role in the task. The simplification process can be carried out by the adult or more capable peer, where the adult or the peer assists the child gradually. As stated previously, Vygotsky claimed that children can learn in the ZPD and they need assistance in this zone (Bekiryazici, 2015).

Students may be able to access more difficult texts when provided a certain level of support (Amendum, Conradi, \& Hiebert, 2017). Long term tutoring program focused on helping students make connections with texts and literacy activities within an environment characterized by caring relationships, a reader who initially finds reading to be a challenge can be successful (Jaeger, 2015). Children who read at least three times a week benefited from the intervention (Knapp, 2016). Thus, teachers must play their role to give guidance to the remedial students. This guidance also known as scaffolding according to Vygotsky's theory of Sociocultural. In this study, ScafoLIT Module is considered as the scaffolding for remedial students in mastering reading comprehension skills.

\section{Intervention Program for Remedial Students}

Since 1960's there are many intervention programs that were created by Ministry of Education Malaysia in order to help remedial students to master reading and writing skills (Malaysia, 2015). Literacy and Numeracy Screening (LINUS) is a program designed by the Ministry of Education Malaysia to solve the problem of the primary school students to master the basic literacy and numeracy skills. This program was launched in 2010 involving all Primary One pupils. The main target of the LINUS program is that all pupils will master basic literacy and numeracy skills in total or achieve 100\% target when they are in Year Three. This intervention program is still ongoing (Malaysia, 2015).

The basic literacy skills in the LINUS program have been ranked into 12 Constructs ranging from the simplest basic skill to more complex skill. Table 1 shows a list of 12 constructs of basic literacy skills in LINUS. 
INTERNATIONAL JOURNAL OF ACADEMIC RESEARCH IN BUSINESS AND SOCIAL SCIENCES

Vol. 9, No. 1, Jan, 2019, E-ISSN: 2222-6990 @ 2019 HRMARS

Table 1: 12 Literacy Constructs for Malay Literacy in LINUS Program

\begin{tabular}{ll}
\hline Constructs & \multicolumn{1}{c}{ Skills } \\
\hline Construct 1 & Able to read and write vowels and consonants. \\
Construct 2 & Able to read and write open syllable words with /CV/ patterns. \\
Construct 3 & Able to read and write open syllable words. \\
Construct 4 & Able to read and write closed syllables. \\
Construct 5 & Able to read and write closed syllable words. \\
Construct 6 & Able to read and write words containing closed syllable /ng/. \\
Construct 7 & Able to read and write a word that contains a diphthong. \\
Construct 8 & Able to read and write a word that contains a united vowel. \\
Construct 9 & Able to read and write words containing digraph and united \\
& consonant. \\
Construct 10 & Able to read and write words with prefixes and suffixes. \\
Construct 11 & Able to read and write simple sentences. \\
Construct 12 & Able to read, write and understand sentences based on stimuli.
\end{tabular}

In the context of LINUS, Ministry of Education Malaysia has provided a learning module to help students mastering the basic literacy skills, but the problem of mastering the basic literacy skills has not been fully resolved. Therefore, this study is used as the basis for producing a literacy learning module in order to help remedial students to master the basic literacy skills.

\section{Research Methodology}

This research was conducted using quantitative methods with survey approach. Respondents of this research is the remedial teachers in Sarawak state which is located in East Malaysia. The purpose of this survey is to investigate the needs and the element that proposed by remedial education teachers for constructing reading comprehension learning modules named Scaffolding Literacy (ScafoLIT). Module Needs Assessment Questionnaire is used to collect the research data. This questionnaire consist of four parts which is named as; (1) Part A demographic data; (2) Part B needs for developing learning module; (3) Part C suggested content of learning module; and (4) Part D suggested teaching and learning design.

The content of the questionnaire used in this study is validated by three panels of experts in the Remedial Education field. Content validity index (CVI) of this questionnaire is at 0.81 . According to (Davis, 1992), a valid questionnaire must got a CVI value of $\geq 0.80$. Reliability of the questionnaire is measured by analyzing the internal consistency of the questionnaire by using cronbach alpha. An alpha value of this questionnaire is $\alpha=.87$ which indicates that this questionnaire is reliable (Creswell, 2010).

The findings of this survey were analyzed using descriptive analysis of the mean value. Interpretation of the mean value is carried out according to recommendations by (Mohamad Najib, 1999) which stated that mean value between 0.00-2.33 is interpreted as low, mean value between 2.34-3.66 is interpreted as a moderate and mean value between 3.67-5.00 is interpreted as high. 
INTERNATIONAL JOURNAL OF ACADEMIC RESEARCH IN BUSINESS AND SOCIAL SCIENCES

Vol. 9, No. 1, Jan, 2019, E-ISSN: 2222-6990 (C) 2019 HRMARS

\section{Research Findings}

Prior to the module development phase, a survey involving 53 remedial teachers was conducted to investigate the need to construct a learning module. The findings of this study will be explained according to the parts of the questionnaire which are; (1) Part A demographic data; (2) Part B needs for developing learning module; (3) Part C content of learning module; and (4) Part D suggested teaching and learning design.

\section{Part A: Demographic Data}

All of remedial teachers in Daro district was selected to be respondents for this survey. There are 53 remedial teachers in this district which consist of 23 males and 30 females. 31 of this remedial teachers are teaching in rural areas and 22 of them teaching in inland areas. Almost all of the remedial teachers in this district completed education at degree level and only five of them are diploma holders. Regarding to teaching experience, 10 of the respondents have less than five years teaching experience, 30 of them have between six to 15 years of teaching experience, while 13 of the respondents have more than 16 years of teaching experience. Figure 1 and Figure 2 conclude the demographic data of the respondents.

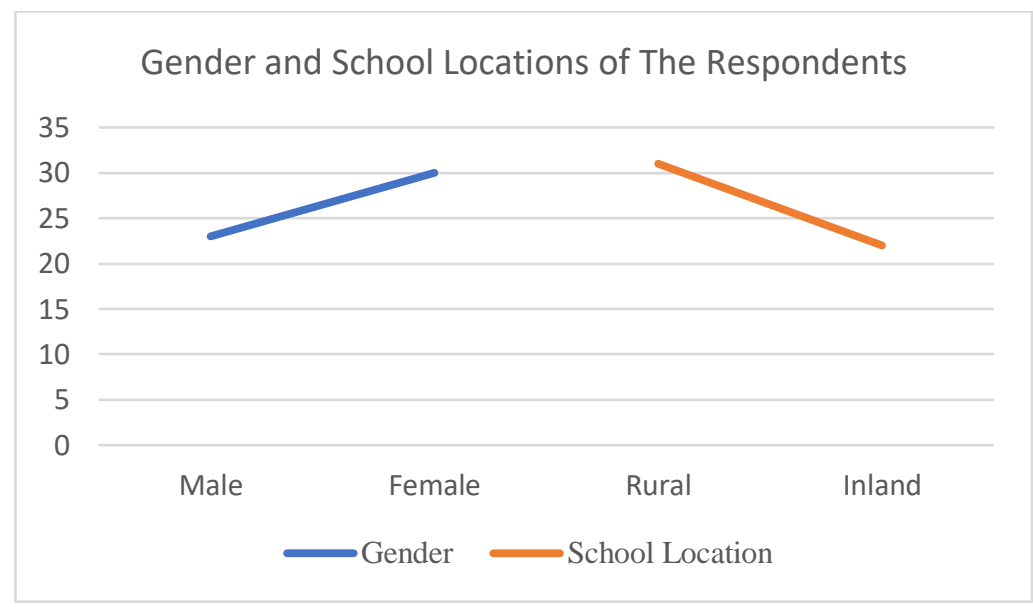

Figure 1: Gender and School Locations of The Respondents 
INTERNATIONAL JOURNAL OF ACADEMIC RESEARCH IN BUSINESS AND SOCIAL SCIENCES

Vol. 9, No. 1, Jan, 2019, E-ISSN: 2222-6990 (C) 2019 HRMARS

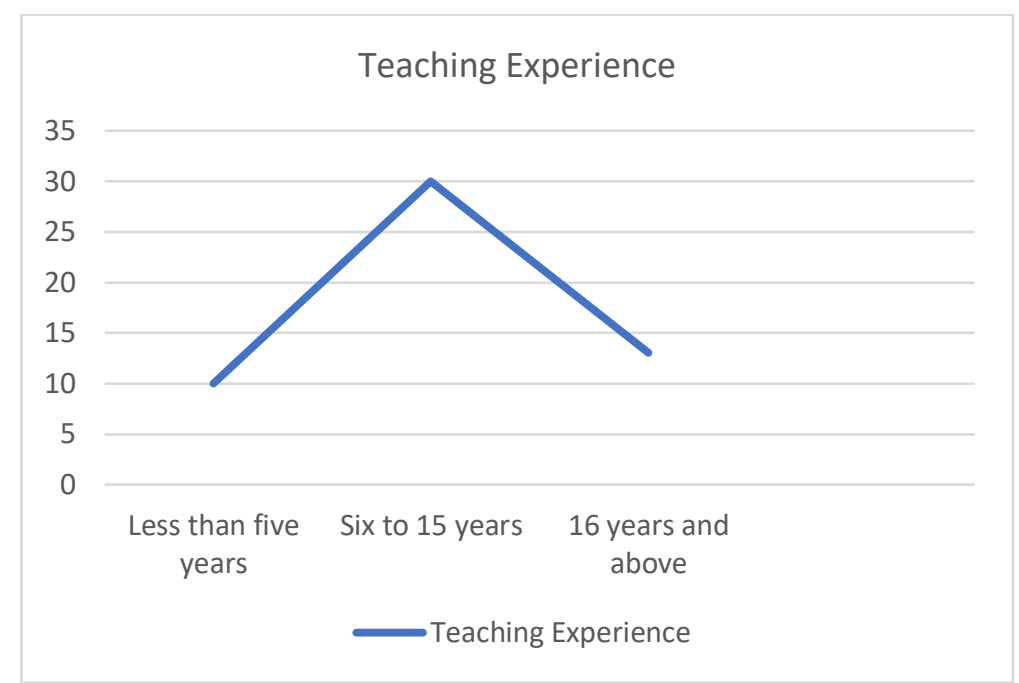

Figure 2: Teaching Experience of The Respondents

\section{Part B: Needs for Constructing Learning Module}

Part B in Module Needs Assessment Questionnaire is focused on the needs for constructing a learning module based on remedial teachers agreement. Basically, this part of the questionnaire is exploring about the problem that remedial teachers might face in teaching and learning and exploring about the problem that remedial teachers might face in the implementation of LINUS and remedial education program in school. The participants are required to choose their scale of agreement between one to five for every item in this part of the questionnaire.

Table 2: Needs for Constructing Learning Module

\begin{tabular}{|c|c|c|c|c|}
\hline \multicolumn{5}{|c|}{ Needs for Constructing Learning Module } \\
\hline No. & Item & $\begin{array}{c}\text { No. of } \\
\text { Participants }\end{array}$ & Mean & Interpretation \\
\hline 1 & $\begin{array}{l}\text { LINUS Learning Module is ineffective for } \\
\text { teaching. }\end{array}$ & & 3.89 & High \\
\hline 2 & $\begin{array}{l}\text { I often have to modify LINUS learning } \\
\text { modules because the levels are very high } \\
\text { for remedial students. }\end{array}$ & & 3.83 & High \\
\hline 3 & $\begin{array}{l}\text { I have inadequate skills to teach remedial } \\
\text { students using LINUS Learning Module } \\
\text { and Remedial Education Learning } \\
\text { Module }\end{array}$ & 53 & 3.00 & Moderate \\
\hline \multirow[t]{2}{*}{4} & $\begin{array}{l}\text { I think that there is a need to construct a } \\
\text { new learning module to help remedial } \\
\text { students mastering reading } \\
\text { comprehension skills. }\end{array}$ & & 4.11 & High \\
\hline & & verage Mean & 3.71 & High \\
\hline
\end{tabular}


Table 2 shows the analysis of mean for Part B needs for constructing a learning module in research instrument. The data show that remedial teachers who participated in this study agreed that there is a need to construct a new learning module for remedial students with average mean 3.71. This average mean value shows that there is a high agreement among the participants about the need to construct a new learning module for remedial students. Thus, based on this findings researcher has decided to build a learning module named ScafoLIT in order to help remedial students mastering their reading comprehension skills.

\section{Part C: Content of Learning Module}

Part $C$ in the questionnaire requires a participant to evaluate the level of consent to the proposed content of the learning module suggested by the researcher. The participants are required to choose their scale of agreement between one to five for every item in this part of the questionnaire. 
INTERNATIONAL JOURNAL OF ACADEMIC RESEARCH IN BUSINESS AND SOCIAL SCIENCES

Vol. 9, No. 1, Jan, 2019, E-ISSN: 2222-6990 @ 2019 HRMARS

Table 3: Content of Learning Module

\begin{tabular}{|c|c|c|c|c|c|c|}
\hline \multicolumn{7}{|c|}{ Content of Learning Module } \\
\hline No & Item & $\begin{array}{c}\text { No. of } \\
\text { Participants }\end{array}$ & Mean & Interpretation & Remarks & \\
\hline 1 & $\begin{array}{l}\text { Learning activities in the module should be based on } \\
\text { the existing knowledge of the remedial students. }\end{array}$ & 53 & 4.30 & High & $\begin{array}{l}\text { Selected } \\
\text { module } \\
\text { element }\end{array}$ & as \\
\hline 2 & $\begin{array}{l}\text { The use of images or illustrations can help remedial } \\
\text { students in reading comprehension process. }\end{array}$ & & 3.96 & High & $\begin{array}{l}\text { Selected } \\
\text { module } \\
\text { element }\end{array}$ & as \\
\hline 3 & $\begin{array}{l}\text { The theme of the reading material in the module } \\
\text { produced should be the same with theme in the KSSR } \\
\text { DSKP }\end{array}$ & & 3.79 & High & $\begin{array}{l}\text { Selected } \\
\text { module } \\
\text { element }\end{array}$ & as \\
\hline 4 & $\begin{array}{l}21^{\text {st }} \text { Century Learning should be integrate in learning } \\
\text { module produced. }\end{array}$ & & 3.23 & Moderate & & \\
\hline \multirow[t]{11}{*}{5} & $\begin{array}{l}\text { LINUS(Literacy) constructs that need to be } \\
\text { emphasized: }\end{array}$ & & & & & \\
\hline & Construct 3 & & 4.15 & High & $\begin{array}{l}\text { Selected } \\
\text { module } \\
\text { element }\end{array}$ & as \\
\hline & Construct 4 & & 3.87 & High & & \\
\hline & Construct 5 & & 3.81 & High & & \\
\hline & Construct 6 & & 3.36 & Moderate & & \\
\hline & Construct 7 & & 3.32 & Moderate & & \\
\hline & Construct 8 & & 2.40 & Moderate & & \\
\hline & Construct 9 & & 2.51 & Moderate & & \\
\hline & Construct 10 & & 2.38 & Moderate & & \\
\hline & Construct 11 & & 2.47 & Moderate & & \\
\hline & Construct 12 & & 2.53 & Moderate & & \\
\hline \multirow[t]{9}{*}{6} & Theme selection & & & & & \\
\hline & Family & & 4.15 & High & $\begin{array}{l}\text { Selected a } \\
\text { module theme }\end{array}$ & as \\
\hline & Cleanliness and Health & & 3.49 & Moderate & & \\
\hline & Unity & & 3.45 & Moderate & & \\
\hline & Culture & & 4.08 & High & $\begin{array}{l}\text { Selected a } \\
\text { module theme }\end{array}$ & as \\
\hline & Identity, Patriotism and Citizenship & & 3.49 & Moderate & & \\
\hline & Agriculture & & 3.79 & High & & \\
\hline & Nature Conservation & & 4.09 & High & $\begin{array}{l}\text { Selected as } \\
\text { module theme }\end{array}$ & as \\
\hline & Integrity & & 3.60 & Moderate & & \\
\hline
\end{tabular}

Table 3 shows descriptive analysis of mean for the Part C Content of Learning Module. The item with high mean interpretation will be considered as an element of the learning module. As we can see from Table 2, item number one to three has a high mean interpretation and this three item will be selected as an element of the learning. While item number six requires the participant to evaluate the most needed LINUS construct to be focusing on the learning module. Most of the participants agreed that Construct 3, Construct 4 and Construct 5 on LINUS (literacy) is needed to be focusing on 
INTERNATIONAL JOURNAL OF ACADEMIC RESEARCH IN BUSINESS AND SOCIAL SCIENCES

Vol. 9, No. 1, Jan, 2019, E-ISSN: $2222-6990$ (c) 2019 HRMARS

the learning module with a mean value of $M=4.15, M=3.87$ and 3.81 respectively. Meanwhile, for the theme selection, three themes with high value of a mean will be selected as a learning module theme. The three themes with high mean value is; (i) Family with a mean value of $M=4.15$, (ii) Culture with a mean value of $M=4.08$ and (iii) Nature Conservation with a mean value of $M=4.09$. Thus, the ScafoLIT module will be focusing on reading and comprehending skills for Construct 3 LINUS and the learning themes will be Family, Culture and Nature Conservation.

\section{Part D: Suggested Teaching and Learning Design}

Part $D$ in the questionnaire is the suggested teaching and learning design proposed by researcher. Respondents need to give their agreement for all the items by using scale one to five.

Table 4: Suggested Teaching and Learning Design

\begin{tabular}{|c|c|c|c|c|c|c|c|}
\hline \multicolumn{8}{|c|}{ Suggested Teaching and Learning Design } \\
\hline No & Item & $\begin{array}{c}\text { No. of } \\
\text { Participants }\end{array}$ & Mean & Interpretation & \multicolumn{3}{|c|}{ Remarks } \\
\hline 1 & $\begin{array}{l}\text { Guidance should be given to students during the } \\
\text { implementation learning module }\end{array}$ & 53 & 4.19 & High & & & \\
\hline 2 & $\begin{array}{l}\text { The reading guidance given to pupils will be reduced } \\
\text { from time to time based on student's current ability }\end{array}$ & & 4.13 & High & & & \\
\hline \multirow[t]{4}{*}{3} & $\begin{array}{l}\text { The appropriate software suggestions are used } \\
\text { together with the reading module during the learning } \\
\text { process. }\end{array}$ & & & & & & \\
\hline & Microsoft Powerpoint & & 3.92 & High & & & \\
\hline & Adobe Captivate & & 3.47 & Moderate & & & \\
\hline & Android Applications & & 4.09 & High & $\begin{array}{l}\text { Selected } \\
\text { module } \\
\text { element }\end{array}$ & & as \\
\hline \multirow[t]{8}{*}{4} & $\begin{array}{l}\text { The following activities are appropriate in the student } \\
\text { module book. }\end{array}$ & & & & & & \\
\hline & Read aloud & & 3.89 & High & $\begin{array}{l}\text { Selected } \\
\text { learning } \\
\text { activity. }\end{array}$ & as & a \\
\hline & Oral communication & & 3.96 & High & $\begin{array}{l}\text { Selected } \\
\text { learning } \\
\text { activity. }\end{array}$ & as & a \\
\hline & Coloring & & 3.91 & High & $\begin{array}{l}\text { Selected } \\
\text { learning } \\
\text { activity. }\end{array}$ & as & a \\
\hline & Match words with pictures & & 3.91 & High & $\begin{array}{l}\text { Selected } \\
\text { learning } \\
\text { activity. }\end{array}$ & as & a \\
\hline & Word search & & 3.51 & Moderate & & & \\
\hline & Sing along & & 3.49 & Moderate & & & \\
\hline & Match sentences with pictures & & 3.96 & High & $\begin{array}{l}\text { Selected } \\
\text { learning } \\
\text { activity. }\end{array}$ & as & a \\
\hline
\end{tabular}


Based on Table 4, respondents agreed that teachers must give a guidance to remedial students in the learning process using learning module. This agreement shown by mean value of 4.19. On the other hand, respondents also agreed that the level of guidance given to the students must be reduced from time to time based on students current achievement with a mean value of 4.13.

Item number three in the questionnaire requires a participant to give their agreement to the suggested software to be used with the learning module. Participants agreed that android applications is suitable to be used along with the learning module with the mean value of 4.09. Lastly, item number four in the questionnaire is the suggested activities to be included in the learning module. According to this item, activities that need to be included in the learning module is (i) read aloud ( $M=3.89)$, (ii) oral communication $(M=3.96)$, (iii) coloring $(M=3.91)$, (iv) match words with pictures $(M=3.91)$ and $(v)$ match sentences with pictures $(M=3.96)$. Hence, it is hoped that suggested teaching and learning by the participants will be able to help remedial students in reading comprehension words and sentences in Malay language.

\section{Conclusion}

ScafoLIT module is the researcher initiative to help remedial students in mastering the reading and comprehension skills in Malay Language Literacy. ScafoLIT module is an alternative for teaching and learning process beside the present literacy module that's been used in school. The ScafoLIT module is an example of scaffolding that can be given to remedial students to pass their ZPDs that are difficulties in mastering reading comprehension skills.

ScafoLIT Module is constructed and designed based on the data from this study. Research finding shows that there is a need to construct a learning module for helping remedial students in mastering reading comprehension skills in the context of Malay Language Literacy. Hence, ScafoLIT Module is the most suitable module that will help students to overcome this problem. This ScafoLIT Module is constructed based on the recommendations by the remedial teachers, then for sure it will be suit for helping remedial students to master the reading comprehension skills.

\section{References}

Amendum, S. J., Conradi, K., \& Hiebert, E. (2017). Does Text Complexity Matter in the Elementary Grades ? A Research Synthesis of Text Difficulty and Elementary Students ' Reading Fluency and Comprehension. Education Psychology, 30, 121-151. https://doi.org/10.1007/s10648-0179398-2

Bekiryazici, M. (2015). Teaching Mixed-Level Classes with a Vygotskian Perspective. Procedia - Social and Behavioral Sciences, 186, 913-917. https://doi.org/10.1016/j.sbspro.2015.04.163

Cirino, P. T., Romain, M. A., Barth, A. E., Tolar, T. D., Fletcher, J. M., \& Vaughn, S. (2013). school struggling readers. Reading and Writing, 26, 1059-1086. https://doi.org/10.1007/s11145-0129406-3

Creswell, J. . (2010). Educational Research-planning, conducting, and evaluating quantitative and qualitative research (Fourth). New Jersey: Pearson Merril Prentice Hall.

Davis, L. L. (1992). Instrument Review: Getting The Most From Your Panel of Expert. Applied Nursing Research, 5(4), 194-197.

Dolezalova, J. (2015). Competencies of Teachers and Student Teachers for the Development of 
INTERNATIONAL JOURNAL OF ACADEMIC RESEARCH IN BUSINESS AND SOCIAL SCIENCES

Vol. 9, No. 1, Jan, 2019, E-ISSN: 2222-6990 @ 2019 HRMARS

Reading Literacy. Procedia - Social and Behavioral Sciences, 171, 519-525.

Jaeger, E. L. (2015). Learning to Construct Meaning From Text : A Case Study of the Relationship Between a Tutor and an English Learner Within a Response to Intervention Setting Learning to Construct Meaning From Text: A Case Study of the Relationship Between a Tutor and an E. Literacy Research Instruction, 285-315. https://doi.org/10.1080/19388071.2015.1062942

Knapp, N. F. (2016). Reading Together: A Summer Family Reading Apprenticeship Program for Delayed and Novice Readers Reading Together: A Summer Family Reading Apprenticeship Program for Delayed and Novice Readers. Literacy Research and Instruction, 55(1), 48-66. https://doi.org/10.1080/19388071.2015.1099767

Malaysia, M. of E. (2015). LINUS 2.0 Operating Guide. Putrajaya: Ministry of Education Malaysia.

Ministry of Education Malaysia. (2013). Malaysia Education Blueprint 2013-2025. Putrajaya: Ministry of Education Malaysia.

Mohamad Najib Abdul Ghafar. (1999). Educational Research. Skudai: Universiti Teknologi Malaysia.

Moschkovich, J. N. (2015). Scaffolding student participation in mathematical practices. ZDM Mathematics Education, 47(7), 1067-1078. https://doi.org/10.1007/s11858-015-0730-3

Pfister, M., Moser Opitz, E., \& Pauli, C. (2015). Scaffolding for mathematics teaching in inclusive primary classrooms: a video study. ZDM - Mathematics Education, 47(7), 1079-1092. https://doi.org/10.1007/s11858-015-0713-4

Rasinski, T. (2016). Is What 's Hot in Reading What Should be Important for Reading Instruction ? Literacy Research Instruction, 134-137. https://doi.org/10.1080/19388071.2016.1135391

Ronkova, J., \& Wildova, R. (2016). Reading Strategies Activated in Experimental Research. Procedia Social and Behavioral Sciences, 217, 363-371. https://doi.org/10.1080/19388071.2015.1027020

Sidek H.M, \& Abdul Rahim. (2015). The Role of Vocabulary Knowledge in Reading Comprehension: A Cross-Linguistic Study. Procedia - Social and Behavioral Sciences, 197(February), 50-56. https://doi.org/10.1016/j.sbspro.2015.07.046

Sung, H. ., \& Shu, F. . (2017). with specific poor comprehension : a systematic review of treatment outcomes. Reading and Writing, 30(4), 917-943. https://doi.org/10.1007/s11145-016-9697-x

Tropper, N., Leiss, D., \& Hanze, M. (2015). Teachers' temporary support and worked-out examples as elements of scaffolding in mathematical modeling. ZDM - Mathematics Education, 47(7), 12251240. https://doi.org/10.1007/s11858-015-0718-z

Wischgoll, A., Pauli, C., \& Reusser, K. (2015). Scaffolding-How can contingency lead to successful learning when dealing with errors? ZDM - Mathematics Education, 47(7), 1147-1159. https://doi.org/10.1007/s11858-015-0714-3

Zhussupova, R., \& Kazbekova, M. (2016). Metacognitive Strategies as Points in Teaching Reading Comprehension. Procedia - Social and Behavioral Sciences, 228, 593-600. 